\title{
The Freedom of Expression in Social Media based on Creator's Moral Right: A Comparative Study
}

\author{
Nico Sunarko Putra ${ }^{1}$, Heniyatun ${ }^{2}$, Chrisna Bagus Edhita Praja ${ }^{3}$, Puji Sulistyaningsih ${ }^{4}$, Hary \\ Abdul Hakim ${ }^{5}$, Muhammad Bagus Boy Saputra ${ }^{6}$, Zulfikar Bagus Pambuko ${ }^{7}$ \\ \{chrisnabagus@ummgl.ac.id ${ }^{3}$ \} \\ Universitas Muhammadiyah Magelang, Magelang, Indonesia ${ }^{1,2,3,4,5,6,7}$
}

\begin{abstract}
The problems in this study include the limitations of the right to integrity in moral rights concerning freedom of expression and the comparative protection of Moral Rights in Indonesia, France, America and Germany. This study is a normative juridical method with a statute approach, conceptual approach, and a comparative approach using primary materials, secondary materials and tertiary materials. The research specifications used are analytical descriptive. The technique of collecting data uses the library research method. The results of the study indicate that there is a limit for users in using the Work of others following Article 27-29 of the ITE Law and the principle of fair use in the provisions of Article 43-50 Copyright Law 2014, and in other clauses using Three-Step Test Analysis (TST). Comparing moral rights protection in Indonesia, France, America, and Germany show equality in regulations due to ratifying the Berne Convention. The fundamental difference is seen in the arrangements in the United States, which focus more on the principle of expediency (Creator Economic Rights) than Moral Rights as in the performance of the State of Indonesia, France, and Germany.
\end{abstract}

Keywords: Right of integrity, freedom of expression, fair use

\section{Introduction}

The international community has long recognized the existence of Copyright as one form of intellectual Work protected by Intellectual Property Rights (IPR). Related Aspects of Trade in Intellectual Property Rights (TRIPs) is one of the agreements signed by Indonesia in the General Agreement on Tariffs and Trade (GATT) documents in Uruguay. The birth of the TRIPs agreement in the Uruguay Round (GATT) impacts international trade and increasingly felt economic conditions that no longer recognize national borders.

The TRIPs Agreement is the most comprehensive international agreement. It is a unique combination of the basic principles of the General Agreement on Tariffs / Trade / GATT (specifically regarding the most favored national and state treatment) with substantive provisions on international intellectual property agreements, including Paris Convention for industrial property protection and the Berne Convention for the Protection of Literary and Artistic Works [1].

Copyright is one of the IPR classifications in the fields of science, art and literature. Based on the provisions in Law No. 28 of 2014, which is from now on referred to as the 2014 Copyright Act Article 1 point 1, it is stated that Copyright is the exclusive right of the Creator that arises 
automatically based on the declarative principle after work is manifested in a tangible form without reducing restrictions in accordance with the provisions of the legislation.

Praja [2] reveals that the Creator certainly wants the results of his Work to be valued and to benefit from publications or commercial benefits. During this time, the recognition and protection of Moral Rights seem to have little place in society, especially in the digital era like today. Whereas in work can reflect the Creator's personality, the impact on Moral Rights that should not be punished by destruction, reduction of creation or other actions that cause interference to the personal Creator. Moral rights also protect the self-reputation of the Creator and show characteristics related to a good name, ability, integrity that the Creator only possesses because Moral Rights are inherent in the Creator even after the Creator dies.

However, the Creator's loss concerning his honor and reputation is difficult to measure. It is due to the absence of parameters to estimate losses for violations seen from integrity rights. It is because the perspective of society in general that considers "habits" is part of freedom of expression. The primary substance "everyone must have the right to freedom of expression" as if it were a fortress of defense as a form of self-actualization or, in other words showing his expression in public [3], [4].

The nature or principle of the Bern agreement is understandable, which aims to protect the author's rights (Copyright) in art, literature and science. The Bern Convention is not just an agreement on how Copyright must be regulated among its member countries. Still, this Convention sets out a minimum set of benchmarks that copyright laws in each country must meet because minimum protection standards cause differences in the conception of arrangements for the protection of moral rights for creators. Based on this, the problem is how to limit the right to integrity in moral rights concerning freedom of expression. So, it is necessary to compare the protection of moral rights in Indonesia with member states of the Berne Convention (France, America, Germany)

Based on the phenomenon and description above, it is interesting to reveal the freedom of expression in social media based on the right of integrity in creators' moral rights by comparing the copyright laws in Indonesia, France, American, and Germany.

\section{Method}

The author uses a normative juridical approach, namely, that uses the conception of positivist legislation [5]. This concept views law as synonymous with written norms made and announced by official institutions or officials. The approach method in this study uses a statue approach, conceptual approach and comparative approach. The research material is primary material in Law No. 28 of 2014 concerning Copyright, Law Number 19 of 2016 concerning Electronic Information and Transactions, France Copyright Law, 1990 US Visual Artist Rights Act, Urheberrechtgesetz Germany. Secondary materials include books, legal writings and legal journals, and tertiary materials including the Legal Dictionary and the Large Dictionary of Indonesian Language.

The research specifications in this study are analytical descriptive specifications with library data collection techniques. Data analysis methods are analyzed legally so that a comprehensive analysis description is produced. 


\section{Results and Discussions}

\subsection{The Limitation of the Right to Integrity in Copyright}

The copyright contained Moral Rights, which are defined as rights inherent in the Creator that cannot be transferred or deleted for any reason even though the Copyright has been assigned. Moral rights include the right of the Creator to be mentioned in creation (the right of attribution or right of paternity) and the right of the Creator to prohibit others from damaging and mutilating their rights (integrity rights) [6], [7].

Moral Rights have meaning that refers to personal rights and have a non-economic dimension [8]. From this right, it can be understood that the dignity of the Creator reflected in the Creation must be respected and protected. The basis that work can reflect the Creator's personality is the originality factor of a copyrighted work originating from the Creator who can show creativity and moral relations between the Creator and his Creation [9].

Recognition of Moral Rights is also included in Article 27 of the Universal Declaration of Human Rights, which states, "Everyone has the right to protect the moral and material interests resulting from any scientific, literary or artistic production of which he is the author." That means that everyone has the right to receive moral and material protection for scientific, literary, or artistic works he creates.

Mainly regarding Moral Rights, the Bern Convention regulates it in Article 6bis, which reads: "...the author shall have the right to claim authorship of the work and to object to any distortion, mutilation or other modification of, or other derogatory action concerning, the said work, which would be prejudicial to his honour or reputation."

The concluded based on the explanation above, Moral Rights is a reflection of the Creator, based on the originality of the Creator's original Work, implicating the moral dimension of a Creator in his Creation. In addition, it can also be understood that other forms of disruption to copy works, such as changes or destruction, can also affect the Creator's person.

Regarding the context of IPR, the clause in Article 43-50 of the 2014 Copyright Act is commonly known as "fair use" [10], [11]. This provision is the scope of restrictions and exceptions made possible by article 13 of the Agreement on Trade-Related Aspects of Intellectual Property Rights (TRIPs), which states that: "Members shall confine limitations or exceptions to exclusive rights to certain special cases which do not conflict with a normal exploitation of the work and do not unreasonably prejudice the legitimate interests of the right holder".

In the 2014 Copyright Act, there are actions related to Fair use, referred to as copyright restrictions and exceptions, including in the Copyright Act Article 43, which mentions acts that do not violate Copyright. The provisions of Article 44 to Article 51 of the Copyright Act state that there is no prohibition on the use of works but must mention or mention the Creator's name. Article 47 of the Copyright Act states that any library or archive institution that does not have a commercial purpose can make 1 (one) copy of the Work or part of creation without the Creator's permission or the copyright holder.

Copyright Law Article 48 states that copying, broadcasting, or communicating for Work for the information that says the source and name of the Creator in full are not considered a violation of Copyright with the provisions of the Work.

Copyright Act Article 50 states that every person is prohibited from making Announcements, Distributing or Communicating Creations contrary to morality, religion, morality, public order or defense and security. 
However, in the context of freedom of expression and the provisions in the 2014 Copyright Act, these provisions are also regulated in the ITE Law [12]. When a user uses someone else's Work and publishes it to social media, if it damages the dignity and reputation of the Creator, the Author may submit a claim for loss under the ITE Law following Article 26 if it is done without the consent of the Author.

However, the regulation of fair use in Indonesia in the 2014 Copyright Act is still unclear from the 'reasonable interest' so that it needs to be interpreted if a legal dispute occurs in the future with an explanation of Article 44: "... balance in enjoying economic benefits etc. ", Especially the view of the public in general where the constraints of IPR protection, including copyrights, among others, the community still considers IPR to be a public rights, which has a social function so that certain people do not mind if other parties copy their products.

Parameters or benchmarks for categorizing reasonable interests that are not contained in the clause Article 43-50 can be analyzed by the Three-Step Test (TST) doctrine or three testing steps as a reference to test whether the use of Creation by others causes harm to the Creator. As long as the use by the user passes the TST test, it can be said that the user does not violate the Work used. According to Joined [4], the Three-Step Test (TST) is a test that is used as a boundary between the Creator's Exclusive Rights and Special Rights and the principal balance to use (privilege to use). The Three-Step Test (TST) includes three stages that are cumulative and based on sequence, i.e. [13]:

a. Criterion 1: Basic Rule: limitation must be a specific unique case

b. Criterion 2: The first condition delimiting the basic rule: no conflict with a normal exploitation-compulsory licenses impossible.

c. Criterion 3: The second condition delimiting the basic rule: no unreasonable prejudice to legitimate interest-compulsory licenses possible.

Based on the description above, the author analyzes that the limitation of the right to integrity concerning freedom of expression must not conflict with Article 43-50 of the Copyright Act 2014. If there is no such clause, it can be tested using the Three-Step Test (TST). If the user's actions do not violate Article 43-50 of the Copyright Act 2014 and pass the TST test, it can be said that the user does not break the boundaries of integrity rights in the Creator's Moral Rights. Thus, users can freely express themselves because derivative works also receive protection in Copyright in the same way as original creations.

The statutory provisions, both the 2014 Copyright Act and the ITE Law, have set limits on users. It is explicitly regulated in Article 43-50 of the 2014 Copyright Act as a reference for users in expression. Other provisions are handled by the Creator if there is a work on social media that is perceived to disturb the dignity and reputation of the Creator.

\subsection{The Comparison of Integrity Rights and Limitation of Copyrighted Works in Indonesia, France, America and Germany}

There are similar arrangements regarding Moral Rights in Indonesia, France, America, and Germany because these countries are joined and ratified the Berne Convention to comply with the minimum standards of protection contained in the Berne Convention [14]. The difference is found in the conception of Moral Rights arrangements, especially in the United States. As Continental European countries, Indonesia, France, and Germany appear to have the same regulatory principle that Copyright is a perpetual, irrevocable (more inalienable) right and emphasizes that Copyright as part of human rights is not property right. In contrast to the arrangement in America as an Anglo-Saxon State, they are regulating Copyright as property 
rights. The principles underlying American Copyright are valuable (more protecting the Creator's Economic Rights), following the opinions of Jeremy Bentham and JS Mills. These namely principles balance the economic interests of producers with the interests of consumers.

The second fundamental difference is that Moral Rights cannot be transferred in settings in Indonesia, France and Germany because Moral Rights are inherent rights in the Creator even to the Creator's death. Another thing in America is that Moral Rights can be transferred/transferred to the ownership of Moral Rights. The limitation of copyright regulation comparation between Indonesia, France, America and Germany is presented in Table 1 to 4.

Table 1. Integrity Rights and Limitation of Copyrighted works in Indonesian Copyright Law 2014

\begin{tabular}{|c|c|c|c|}
\hline Legislation & $\begin{array}{l}\text { Right of Attribution/Right of } \\
\text { Integrity }\end{array}$ & $\begin{array}{c}\text { Limitations/Waiv } \\
\text { ers/Consent }\end{array}$ & Information \\
\hline $\begin{array}{l}\text { Law Number } \\
28 \text { of } 2014 \\
\text { concerning } \\
\text { Copyright }\end{array}$ & $\begin{array}{l}\text { Article 5(1) The moral rights as } \\
\text { referred to in Article } 4 \text { are rights that } \\
\text { are eternally attached to the Creator to: } \\
\text { a. continue to include or not include } \\
\text { his/her name on the copy in } \\
\text { connection with the public use of the } \\
\text { Work; } \\
\text { b. use his alias or pseudonym; } \\
\text { c. change the Work following the } \\
\text { decency in society; } \\
\text { d. change the title and sub-title of the } \\
\text { Works; and } \\
\text { e. defend their rights in the event of } \\
\text { distortion of Works, mutilation of } \\
\text { Works, modification of Works, or } \\
\text { things detrimental to their honour or } \\
\text { reputation. }\end{array}$ & $\begin{array}{l}\text { The limitation on } \\
\text { Indonesian } \\
\text { Copyright Law } 2014 \\
\text { can be seen in } \\
\text { Articles } 44-51 .\end{array}$ & $\begin{array}{l}\text { Article } 5 \text { (2) The moral rights } \\
\text { referred to in paragraph (1) } \\
\text { cannot be transferred as long as } \\
\text { the author is still alive. Still, the } \\
\text { exercise of these rights can be } \\
\text { shared by a will or other } \\
\text { reasons in accordance with the } \\
\text { provisions of the legislation } \\
\text { after the Author dies. } \\
\text { In the event of a transfer of the } \\
\text { exercise of moral rights as } \\
\text { referred to in paragraph (2), the } \\
\text { recipient may waive or refuse } \\
\text { the exercise of his rights on } \\
\text { condition that the release or } \\
\text { rejection of the movement of } \\
\text { the rights is stated in writing. }\end{array}$ \\
\hline
\end{tabular}

Table 2. Limitation of Copyrighted works in France Copyright Law

\begin{tabular}{|c|c|c|c|}
\hline Legislation & $\begin{array}{l}\text { Right of Attribution / } \\
\text { Right of Integrity }\end{array}$ & Limitations/Waivers/Consent & Information \\
\hline $\begin{array}{l}\text { Law on } \\
\text { Intellectual } \\
\text { Property Rights } \\
\text { (Legislative } \\
\text { Section) (No. } \\
92-597 \text { dated } \\
\text { July } 1 \text { 1992, as } \\
\text { last amended by } \\
\text { Laws No. 94- } \\
361 \text { dated May } \\
10 \text { 1994, and 95- } \\
4 \text { dated January } \\
3 \text { 1995). }\end{array}$ & $\begin{array}{l}\text { Attribution } \\
\text { Art. L. 121-1: } \\
\text { A creator can enjoy the } \\
\text { rights to his name, } \\
\text { authorship and Work. } \\
\text { This right belongs to the } \\
\text { Creator. Eternal, } \\
\text { inalienable } \\
\text { unchangeable. This right } \\
\text { can be transferred to the } \\
\text { heirs of the Creator. Or it } \\
\text { can be given to someone } \\
\text { else under the terms of a } \\
\text { will. } \\
\text { Right to reveals } \\
\text { Art. L. 121-2. The Creator } \\
\text { himself has the right to } \\
\text { express his Work. The right } \\
\text { to determine the method of } \\
\text { disclosure and the right to } \\
\text { withdraw the Work to } \\
\text { improve the conditions that }\end{array}$ & $\begin{array}{l}\text { The copyright characteristic } \\
\text { Art. L. 111-1. The Creator can } \\
\text { enjoy the rights to his Work, } \\
\text { only by the fact of its creation, } \\
\text { as an exclusive property that } \\
\text { must be enforced on everyone. } \\
\text { Attribution } \\
\text { This right must include } \\
\text { attributes of an intellectual and } \\
\text { moral nature and attributes of an } \\
\text { economic nature, as determined } \\
\text { by books I and III of this Code. } \\
\text { The existence or conclusion of a } \\
\text { contract to be hired or serviced } \\
\text { by the Creator shall in no way } \\
\text { detract from the enjoyment of } \\
\text { the rights granted by the first } \\
\text { paragraph above. }\end{array}$ & $\begin{array}{l}\text { Art. L. 111-3. Incorporeal } \\
\text { property rights regulated } \\
\text { in Article L. 111-1 must be } \\
\text { independent of property } \\
\text { rights in physical objects. } \\
\text { The acquisition of such } \\
\text { objects shall not entitle the } \\
\text { acquirer of anything to the } \\
\text { rights conferred by this } \\
\text { Code, except in the cases } \\
\text { mentioned in the provisions } \\
\text { of the second and third } \\
\text { paragraphs of Article L. 123- } \\
4 . \\
\text { These rights must exist in the } \\
\text { Creator or his successor who } \\
\text { owns the rights, which may } \\
\text { not require the owner of the } \\
\text { physical object to make the } \\
\text { thing available to them to } \\
\text { exercise those rights. } \\
\text { However, in the event of }\end{array}$ \\
\hline
\end{tabular}




\begin{tabular}{|c|c|c|c|}
\hline Legislation & $\begin{array}{l}\text { Right of Attribution / } \\
\text { Right of Integrity }\end{array}$ & Limitations/Waivers/Consent & Information \\
\hline & $\begin{array}{l}\text { exist in it, subject to Article } \\
\text { L. } 132-24 \text {. }\end{array}$ & & $\begin{array}{l}\text { actual abuse by the owner } \\
\text { preventing the movement of } \\
\text { the right of disclosure, the } \\
\text { court of the first instance } \\
\text { (tribunal de grande instance) } \\
\text { may take appropriate action } \\
\text { according to the provisions } \\
\text { of Article L. 121-3. }\end{array}$ \\
\hline
\end{tabular}

Table 3. Limitation of Copyrighted works in American Copyright Law

\begin{tabular}{|c|c|c|c|}
\hline Legislation & $\begin{array}{c}\text { Right of Attribution/Right } \\
\text { of Integrity }\end{array}$ & Limitations/Waivers/Consent & Information \\
\hline $\begin{array}{l}\text { Title } 17 . \\
\text { Copyright } \\
\text { (Copyright Law } \\
\text { 1976 (Public } \\
\text { Law 94-553 of } \\
\text { October 19, } \\
\text { 1976), } \\
\text { last amended by } \\
\text { Public Law 104- } \\
39 \text { dated } \\
\text { November 1, } \\
\text { 1995)* }\end{array}$ & $\begin{array}{l}\text { Section 106A. Certain Author } \\
\text { rights to attribution and } \\
\text { integrity } \\
\text { (a) Right of attribution and } \\
\text { integrity. Subject to section } \\
107 \text { and independent of the } \\
\text { exclusive rights provided for } \\
\text { in section 106, the Creator of } \\
\text { the visual artwork } \\
\text { (1) has the right (A) to claim } \\
\text { the authorship of the Work, } \\
\text { and (B) to prevent the use of } \\
\text { his name as the Creator of any } \\
\text { work of visual art that he does } \\
\text { not create; (2) has the right to } \\
\text { prevent the use of his name as } \\
\text { the Creator of visual artwork } \\
\text { in the event of a distortion, } \\
\text { mutilation, or other } \\
\text { modification of the Work } \\
\text { which will harm his honor or } \\
\text { reputation; and (3) subject to } \\
\text { the limitations set out in } \\
\text { article } 113 \text { (d), entitled } \\
\text { (a) to prevent any intentional } \\
\text { deviation, mutilation, or other } \\
\text { modification of the Work } \\
\text { which would be detrimental } \\
\text { to his honor or reputation, and } \\
\text { any deliberate departure, } \\
\text { mutilation or modification of } \\
\text { the Work constitutes an } \\
\text { infringement of that right, and } \\
\text { (b) to prevent the destruction } \\
\text { of a work of recognized } \\
\text { status, and the intentional or } \\
\text { unintentional destruction of } \\
\text { that Work constitutes a } \\
\text { violation of that right }\end{array}$ & $\begin{array}{l}\text { 106A (e) Transfers and waivers. } \\
\text { (1) The rights granted by } \\
\text { paragraph (a) may not be } \\
\text { transferred, but those rights may } \\
\text { be waived if the author expressly } \\
\text { agrees to such waiver in a written } \\
\text { instrument signed by the Author. } \\
\text { Such an instrument should } \\
\text { specifically identify the Work and } \\
\text { use of that Work, where the } \\
\text { waiver applies, and the waiver } \\
\text { applies only to the recognized } \\
\text { Work and use. In the case of joint } \\
\text { Work prepared by two or more } \\
\text { authors, a waiver of rights under } \\
\text { this paragraph made by one such } \\
\text { author waives such rights for all } \\
\text { such authors. } \\
\text { (2) Ownership of the rights } \\
\text { granted by paragraph (a) } \\
\text { concerning a work of visual art } \\
\text { differs from ownership of any } \\
\text { copy of that Work or Copyright or } \\
\text { exclusive rights under Copyright } \\
\text { in that Work. The transfer of } \\
\text { ownership of any copy of the } \\
\text { visual artwork or any copyright or } \\
\text { other exclusive right under } \\
\text { copyright shall not constitute a } \\
\text { waiver of the rights granted by } \\
\text { paragraph (a). Except as may be } \\
\text { agreed to by the Author in a } \\
\text { written instrument signed by the } \\
\text { Author, a waiver of the rights } \\
\text { granted by paragraph (a) in respect } \\
\text { of a work of visual art will not } \\
\text { constitute a transfer of ownership } \\
\text { of any copies of that Work. or } \\
\text { ownership of any copyright or } \\
\text { other exclusive rights under } \\
\text { Copyright in that Work. } \\
\text { (Added Pub. L. } 101-650 \text {, heading } \\
\text { 1990, 104 Stat. } 5128 \text {.) }\end{array}$ & $\begin{array}{l}\text { Section 106A (3) The } \\
\text { rights described in } \\
\text { paragraphs (1) and (2) of } \\
\text { paragraph (a) do not } \\
\text { apply to the } \\
\text { reproduction, depiction, } \\
\text { depiction, or other use of } \\
\text { work on, above, or in } \\
\text { any connection with the } \\
\text { goods. whatever is } \\
\text { explained in the sub } \\
\text { verse (A) or (B) of the } \\
\text { definition of "work of } \\
\text { visual art" in section } \\
\text { 101, and any } \\
\text { reproduction, depiction, } \\
\text { depiction, or other use of } \\
\text { a work is not the } \\
\text { destruction, distortion, } \\
\text { mutilation, or further } \\
\text { modification described } \\
\text { in paragraph (3) } \\
\text { paragraph (a). } \\
\text { (d) Duration of } \\
\text { entitlement. } \\
\text { Concerning works of } \\
\text { visual art created on or } \\
\text { after the effective date } \\
\text { set out in section } 610 \text { (a) } \\
\text { of the Visual Artists } \\
\text { Rights Act 1990, the } \\
\text { rights granted by } \\
\text { paragraph (a) will last } \\
\text { for a period consisting of } \\
\text { life Creator. }\end{array}$ \\
\hline
\end{tabular}


Table 4. Limitation of Copyrighted works in Germany Copyright Law

\begin{tabular}{|c|c|c|c|}
\hline Legislation & $\begin{array}{c}\text { Right of Attribution/Right } \\
\text { of Integrity }\end{array}$ & $\begin{array}{c}\text { Limitations/Waivers/ } \\
\text { Consent }\end{array}$ & Information \\
\hline $\begin{array}{l}\text { Law on Copyright } \\
\text { and Neighbors' } \\
\text { Rights (Copyright } \\
\text { Law) (September } 9 \\
\text { 1965, as last } \\
\text { amended by Law } 24 \\
\text { July 1996). }\end{array}$ & $\begin{array}{l}\text { Publication Rights } \\
\text { Art. 12.- (1) The author has } \\
\text { the right to decide whether } \\
\text { and how his Work will be } \\
\text { published. } \\
\text { (2) The author has the } \\
\text { exclusive right to publicly } \\
\text { communicate or describe the } \\
\text { content of his Work as long as } \\
\text { the Work or its essence or } \\
\text { description of the Work has } \\
\text { been published with his } \\
\text { consent. } \\
\text { Art Recognition (Attribution) } \\
\text { Art. 13. The author has the } \\
\text { right to acknowledge the } \\
\text { authorship of his Work. He } \\
\text { can decide whether the Work } \\
\text { will result in the Creator } \\
\text { designation and what } \\
\text { designation will be used. } \\
\text { Art. 14. The author has the } \\
\text { right to prohibit any distortion } \\
\text { or mutilation of his Work that } \\
\text { may harm his legitimate } \\
\text { intellectual or personal } \\
\text { interests in the Work. }\end{array}$ & $\begin{array}{l}\text { The difference between } \\
\text { moral rights and economic } \\
\text { rights (exploitation). } \\
\text { Job Change } \\
\text { Art } 39-(1) \text { The } \\
\text { exploitation right holder } \\
\text { may not change the Work, } \\
\text { its title or the designation of } \\
\text { the Author (Article } 10 \text { (1)) } \\
\text { unless otherwise agreed. } \\
\text { (2) Changes to the Work } \\
\text { and its title, which the } \\
\text { Author cannot reasonably } \\
\text { refuse, are permitted. }\end{array}$ & $\begin{array}{l}\text { Section V Dealings with } \\
\text { Rights in Copyright } \\
\text { Copyright Inheritance } \\
\text { Art. 28.- (1) Copyright } \\
\text { can be transferred by } \\
\text { inheritance. } \\
\text { (2) The author may } \\
\text { transfer the exercise of } \\
\text { the Copyright to the } \\
\text { executor with the } \\
\text { disposition of a will. } \\
\text { Article } 2210 \text { of the Civil } \\
\text { Code does not apply. } \\
\text { Copyright Transfer } \\
\text { Art. } 29 . \text { Copyright is not } \\
\text { transferable. However, it } \\
\text { can be transferred in the } \\
\text { implementation of the } \\
\text { disposition of the will or } \\
\text { to the heirs } \\
\text { Successor in Title Art } \\
\text { Creator. } 30 \text { In the } \\
\text { absence of conflicting } \\
\text { provisions, the successor } \\
\text { in the title of Creator will } \\
\text { have the rights granted to } \\
\text { the Author by this Law. }\end{array}$ \\
\hline
\end{tabular}

\section{Conclusion}

Limitations on the right of integrity about freedom of expression must not conflict with Article 43-50 of the 2014 Copyright Law. If it is not contained in the clause, it can be tested using the Three-Step Test (TST). Suppose the copier's actions do not violate the clauses of Article 43-50 of the 2014 Copyright Law and pass the TST test. In that case, it can be said that the copier has not violated the limits in the right of integrity in the Creator's Moral Rights. The similarity in the regulation of moral rights in Indonesia, France, America and Germany is because these countries have joined and ratified the Berne Convention to comply with the minimum standards of protection contained in the Berne Convention. There is a clear difference in the conception of the regulation of Moral Rights, especially in the United States. Indonesia, France and Germany, like Continental European countries, seem to have the same regulatory principle that Copyright is an eternal right (perpetual), cannot be revoked (inalienable) and emphasizes that Copyright is part of Human Rights. Property rights. The second fundamental difference is that Moral Rights cannot be transferred either in the regulations in Indonesia, France and Germany because Moral Rights are eternally attached to the Creator even until the Creator dies. It is different in America that Moral Rights can be transferred/transferred to the ownership of Moral Rights. 


\section{References}

[1] M. Abdulkadir, Kajian Hukum Ekonomi Hak Kekayaan Intelektual. Bandung: Citra Aditya Bakti, 2001.

[2] Dharmawan, NI Ketut Supasti, and W. Wiryawan, "Keberadaan dan Implikasi Prinsip MFN dan NT Dalam Pengaturan Hak Kekayaan Intelektual Di Indonesia," J. Magister Huk. Udayana, vol. 6, no. 2, pp. 2302-5280, 2014.

[3] Heniyatun, Heniyatun, P. Sulistyaningsih, and H. Hendrawati, "Kajian Yuridis Peralihan Hak Cipta Sebagai Objek Wakaf," J. Huk. Nov., vol. 6, no. 2, pp. 1412-6834, 2017.

[4] M. Fagih, Panduan Pendidikan Polik Rakyat. Yogyakarta: Insist, 1999.

[5] J. Ibrahim, Teori dan Metodologi Penelitian Hukum Normatif. Malang: Bayumedia Publishing, 2006.

[6] Bbot, F. Gurry, H. Cottler, and Francis, The International Intellectual Property System:Commentary and Materials, 1st ed. London: The Haque, 1999.

[7] H. C. Black, Black's Law Dictionary Fifth Edition, 4th ed. London: West Pub. Co, 1979.

[8] Mashdurohatun, A. Dan, and M. A. Mansyur, Identifikasi Fair Use/Fair Dealing Hak Cipta Atas Buku Dalam Pengembangan Iptek Pada Pendidikan Tinggi Di Jawa Tengah. Bandung: Citra Aditya Bakti, 2015.

[9] A. S. Oddi, “TRIPS-Natural Right and A 'Polite From of Economic Imprerialism."” p. 415, 1996.

[10] Cornish and Liewelyn, Intellectual Property: Patents, Copyright, Trade Marks and Allied Rights. London: Thomson Sweet \& Maxwell, 2003.

[11] M. Djumhana, Perkembangan Doktrin dan Teori Perlindungan Hak Kekayaan Intelektual. Bandung: PT Citra Aditya Bakti, 2006.

[12] S. Dirdjosisworo, Kontrak Bisnis (Menurut Sistem Civil Law, Common Law, dan Praktek Dagang Internasional). Bandung: Mandar Maju, 2003.

[13] H. Paserangi, "Perlindungan Hukum Hak Cipta Software Program Komputer di Indonesia." Yogyakarta, 2014, [Online]. Available: http://law.uii.ac.id/images/stories/Jurnal Hukum/13_Hasbir Paserangi.pdf, diakses pada tanggal 5 Oktober 2018, pukul 10.26.

[14] C. P. Rigamonti, "The Conceptual Transformation of Moral Rights," Am. J. Comp. Law, vol. 55, no. 1, pp. 67-122, 2007. 